\title{
Barely Bonded: Affective Politics and the Gendered Struggle for Water in Villa El Salvador, Lima, Peru
}

Kyle Woolley

Assumption College

Kelly Moore

Loyola University Chicago, kmoore11@luc.edu

Follow this and additional works at: https://ecommons.luc.edu/soc_facpubs

Part of the Sociology Commons

Author Manuscript

This is a pre-publication author manuscript of the final, published article.

\section{Recommended Citation}

Woolley, Kyle and Moore, Kelly. Barely Bonded: Affective Politics and the Gendered Struggle for Water in Villa El Salvador, Lima, Peru. Qualitative Sociology, 43, : 165-189, 2020. Retrieved from Loyola eCommons, Sociology: Faculty Publications and Other Works, http://dx.doi.org/10.1007/ s11133-020-09448-x

This Article is brought to you for free and open access by the Faculty Publications and Other Works by Department at Loyola eCommons. It has been accepted for inclusion in Sociology: Faculty Publications and Other Works by an authorized administrator of Loyola eCommons. For more information, please contact ecommons@luc.edu. cc) (i) $\ominus$

This work is licensed under a Creative Commons Attribution-Noncommercial-No Derivative Works 3.0 License. (c) Springer, 2020. 
Title: Barely Bonded: Affective Politics and the Gendered Struggle for Water in Villa El Salvador, Lima, Peru

\title{
Authors:
}

Kyle Woolley

Department of Sociology and Criminology

Assumption College

500 Salisbury Street

Worcester, MA 01609

Email: k.woolley@assumption.edu

Kelly Moore

Department of Sociology

Loyola University Chicago

1032 W. Sheridan Ave.

Chicago, IL 60660

\section{Author Bios:}

Kyle Woolley is a Visiting Assistant Professor of Sociology at Assumption College in Worcester, Massachusetts. His areas of interest are in the sociology of gender and poverty, family life, and social movements in Latin American cities and more broadly.

Kelly Moore is Associate Professor of Sociology at Loyola University Chicago. Her research interests are in the creation and political challenges to the relationships between capitalism, genderrace, militarism, and material and technical systems. Her latest project examines the rise of gendered and raced resilience science in the context of militarized neoliberalism in the USA

\begin{abstract}
:
Affect is increasingly understood as a critical element of political life and collective action in Latin America and elsewhere. It is critical to generating participation in collective action projects, sustaining or collapsing action, and how participants interpret the meanings and values of a project and the social relationships within it. More broadly, affective political experiences are markers of the sense of belonging or disaffection from others and broader political systems that are central to civic life. The meanings of participation after projects fade are often attributed mainly to the collective events themselves, and draw on one-off interviews after the events decline, or short ethnographies relatively close in time to the collective actions. As well, they often foreground the positive experiences that participants recall from collective action. Using 48 interviews and three years of participant observation, which followed 12 years of political and social engagement with
\end{abstract}


women residents of Villa El Salvador (VES) in Lima, Peru, we challenge all three of these perspectives. The women were involved in a 20 -year, materially successful, brokered collective action project to install water and sanitation systems in their neighborhood. The data reveal that long-term participants recalled actions in collective terms, but recounted affective experiencesmainly senses of abandonment and struggle - in individualistic terms. Unlike what most studies of collective action have concluded, these stories of being "barely bonded" to co-participants and leaders were not attributed to the collective actions themselves: they were told as part of stories of life-long gendered experiences of personal and state violence, state and family abandonment, and corrupt political practices in Peru. These affects were expressed with an insistence on sympathy from author 1, who has had long-term care relationships with people in VES. The methods and findings extend Latin American collective action scholarship that has documented disappointment and civil disaffection as outcomes of collective action, showing that longer-term forms of politics and relationships in which people's political lives unfold (including with analysts), rather than collective action projects themselves, can reveal richer senses of the meanings of participation in collective action for civic life.

Keywords: Collective action; Solidarity; Affective politics; Clientelism; Violence; Peru 


\section{The Affective Politics of Organizing for Water}

Walking through the waterlogged wooden door that separated her living space from the damp sand that formed the street in front of her home in Lima, Peru's Villa El Salvador (VES) district, Lorena pointed to a thin pipe that emerged from her dirt floor, capped by a leaking valve that fed a rubber hose. Using the hose, she began to fill plastic buckets on her kitchen floor. Another bucket caught the water that leaked through the rusted tin roof. While it rarely rains in Lima, the fine mist that falls in the winter months quickly accumulates in and on homes without solid roofs. As imperfect as it is, the water system in Lorena's home took more than two decades of often difficult collective action by women like her to acquire. With bitterness in her voice, Lorena recounted her own sacrifices:

From the time I came to VES, I have helped the dirigentes [organizers, or brokers]. Always supporting. I did whatever they needed me to do. I went to every march and every assembly. I had to because if not, you got fined 50 soles. I also sold whatever I could to collect money to pay for the bus fare and food for the dirigentes because they had to take buses to meetings and talk to SEDAPAL [the public/private water company that eventually provided the water system], and that all costs money.

Like many other of the women, Lorena no longer participated in neighborhood political assemblies or other political activities, and said that she had only minimal contact with other residents, participating only occasionally in events for children such as birthday parties. Lorena's story of personal suffering and political disaffection is reflected in the stories of other women who participated in the 1992-2012 collective for water and sanitation in their neighborhood. What is most striking is that they consistently referred to the political actions and activities in collective 
terms, i.e., by using the term "we" to describe what was done, but their affective interpretations almost always emphasized their own suffering and struggle, not that of others. The affective experience of the water campaign was thus expressed as a feeling of being barely bonded with others in their neighborhood, representing the very opposite of what Bayón and Saraví (2019), appropriating an older concept, call "convivencia": identification and solidarity with others in the neighborhood. Unlike what many other analysts have emphasized about affect and collective action - that the actions themselves, and the political forms that are used, play the major role in shaping affect-in the interviews with the women in VES, the "barely bonded" sensibility was never attributed just to the water campaign experience itself: it was expressed as yet another gendered experience of lives lived in and around violence, of abandonment by the state and kin, and of experiences of long-standing political corruption.

The importance of these stories is that they are a gauge of the character of civic life for materially poor women in Lima, one of non-care and abandonment, even after a major political victory in the form of a new water system. Situating women's stories of collective action in the context of scholarship on social movements and affect, as well as clientelist politics and gendered political life in Latin America, we show that long histories of violence and abandonment can shape the way that people interpret their collective action experiences long after they are over.

\section{Affect in Collective Action Projects}

Affect was largely absent from the sociological study of social movements and collective action in democratic societies prior to 1990, in part because of the influence of rationalist theories of politics that were developed to understand, and to shape, democratic civic life in ways that did not 
depend on the kinds of emotional appeals that were understood to be a basis of fascism, totalitarianism, and civil unrest (Cohen-Cole 2016; Le Bon; 1977; Olson 1965). Among the precursors to the renewed interest in affect, Frantz Fanon (1963), Alain Touraine (1971), analysts of radical education projects (Freire 1970) and consciousness raising (Kravetz 1978), emphasized the importance of affect in recognizing oneself as a political subject and imagining futures. But with the exception of Touraine, they played little role in the sociological understanding of collective action and affect that emerged decades later, which was strongly influenced by strategic and rationalist frameworks of writers such as McAdam (1982) and Olson (1965), who were interested in what conditions promoted the sense that success was possible through collective action. A new body of work extended these logics, tracing the strategic use of emotion in generating and sustaining collective action in democratic societies, often treating it as distinct from cognition (Goodwin, Jasper and Polletta 2001; Jasper 1998; Navarro 2001; Smith 1998). Mobilization and the ongoing process of organizing remain the central foci of most sociological scholarship on affect and collective action.

Subsequent studies have placed affect at the center of what generates action. Sadness, shame, fear, and optimism (Gould 2009; Gravante and Poma 2018; Shepard 2011; Whittier 2009, Young 2007) are now understood to help generate political mobilizations. Moreover, when movements are underway, participants experience often contradictory feelings, such that hope, pride, and optimism can co-exist with fear, hopelessness, and frustration (Arditti 1999; Chisholm 2018; Dernikos 2016; Harris 2018; Kleres and Wettergren 2017; McAdam 1986). Overwhelmingly, these studies tend to focus on collective action as it emerges and unfolds, not when it is over, with some critical exceptions. 
Among those studies that investigate affective interpretations of politics after collective action is over, there are also a wide range of affective attributions, regardless of the perceived success of the campaign (Hanson and Lapegna 2018; Gould 2009; McAdam 1982; Whittier 1995; Yang 2000). Some of these studies have studied affective interpretations in the "demobilization" period (Lapegna 2013). These studies have tended to treat the collective action project itself (and leadership within it) to be a key source of affective experience, a "time out of time" that is understood as singular.

Among those that use biographical methods to trace the long-term affective interpretations of collective action in the USA are McAdam's study of participants in the civil rights "Freedom Summer" campaign and Whittier's examination of feminist generations. Both describe participants' involvement as exhilarating, frightening, and erotic, among other feelings, and say that participation transformed their lives and shaped their choices about work, relationships, and politics. The subjects of these important studies of biography and the affects of social movement involvement, however, were mostly well-off people in a country where few of their freedoms to choose how to live and feel after a political movement ended were restricted. Neither foreground how the relationship between those who are studied and the researchers shape what stories are told.

\section{Affect and Latin American Collective Action}

Analysts of Latin American collective organizing by contrast, have been much more attentive to the partially- or un-democratic systems in which collective action is experienced and to the heterogeneity of political actors and forms in the region. Javier Auyero's (2000) foundational work on the affective politics of survival in post-Peronist Argentina set a new agenda for the sociological 
analysis of Latin American popular politics by linking it to formal political systems. Senses of belonging are now understood to be politically and sociologically important as formal representation and material distribution (Alvarez et al. 2017; Auyero, 2000; Auyero and Swistun 2009; Combes 2018; Hanson 2018; Hanson and Lapegna 2018; Hilgers 2012; Hurtado 2014; Montambeault and Goirand 2016; Quirós 2018). More broadly, Rubin, Smilde and Junge (2014) have emphasized the need to attend to anxieties about trust, care, civility, and material wellbeing in everyday Latin American life, especially in its "zones of crisis" where the poor and the marginally not-poor are in continual struggles to meet basic material needs and to ensure senses of dignity.

Studies from Latin America are particularly powerful in capturing how people make sense of their participation in novel forms of collective political action that include development experiments, first-time engagement in democratic politics, and hybrid forms of social movements and clientelism. These include feelings of ambivalence and frustration about collective action processes and their outcomes (Álvarez Rivadulla 2017; Arce 2008; Baiocchi and Corrado 2010; Bennett et al. 2013; Rubin 1997; Thayer 2010), affection for leaders (Auyero 2000), and the sense that collective action participation is a life-affirming escape from other troubles (Pérez 2018) and a morally meaningful way of life (Nepstad 2004, 2007). More rarely, socially disruptive feelings, such as envy (Junge 2014) and fear (Copeland 2014; Gay 2012; Penglase 2009), are emphasized, and traced in part to the existence of religious frameworks, and the routine and local use of physical violence to enforce political rule, respectively.

In the Latin American context, biographical approaches to the intersection of collective action and affect (Auyero 2003; Di Marco 2017; Navarro 2001; Pérez 2018; Perry 2013) have been an especially powerful way of understanding these affective civic relationships, because they 
refuse to assume that collective action projects are, a priori, affectively unique, but rather allow participants to articulate continuities and discontinuities with other local and specific political experiences. Statements about "choice" that are common in studies informed by USA/EU perspectives are often absent in these studies, too. The stories that the women in the water project told, extend this line of work by demonstrating that specific qualities of Peruvian political life were salient to the participants, qualities that are not identical to those in other times and places, but share some attributes of some forms of Latin American politics.

Specifically, because Latin American governmental regimes, forms of political participation, and distributions of social rights are highly varied and in some places unstable (Chisholm 2018; Copeland 2014; Hanson and Lapegna 2018; Holston 2009; Pérez 2018), their affective qualities cannot be read from abstract formulas, nor from the logics of collective action in places like the USA and the EU, where long histories of civic associationalism, stable governments, and relatively strong democratic institutions are the starting points for understanding affect and collective actions. An approach from the perspective of Latin American politics is thus necessary. As Rubin (1997) makes clear, attention to specific political histories is critical for understanding how emotions are experienced in collective action; it can also illuminate power dynamics that more exclusively micro-scale analyses may not address (Abu-Lughod 1990). Moreover, ethnographic observation is a critical means by which these relationships can be understood, as Hanson and Lapegna (2018) demonstrate in their comparison of the varied interpretations of political mobilization in Venezuela and Argentina under Chávez and Kirchner, respectively, and others have also shown in other contexts (Combes 2018; Harris 2018; Copeland 2014; Nepstad 2004; Rubin 1997; Quíros 2018). In a similar vein, political circumstances and 
cultures are experienced by groups within a country in different ways, suggesting the need for attention to how social groups, not just citizens writ large, experience collective action projects.

\section{Gender, Social Movements, and Development in Latin America}

Women have played critical roles in virtually every political movement in Latin America, and play an increasingly active in role advocating for and the implementation of development projects. These projects include securing access to food, land, and water; improving the efficiency of business and agricultural work; and mobilizing for political rights in the absence of routinized state provision of these benefits (Fernández Kelly and Shefner 2010; Jaquette 2009; Lind 1997; Neumann 2013; Ray and Korteweg 1999; Richards 2005). This work is often unpaid, which increases the burden women often already confront in providing family care and income (Lind 2005; Molyneux 2008; Neumann 2013). Analysts of development politics, however, have rarely engaged the affective experiences of women political organizers that feminist scholarship on Latin American collective action has long emphasized as a component of forging power relations, building coalitions, and addressing tensions (Di Marco 2017; Lind 2005; Navarro 2001; Perry 2013; Saporta et al. 1992; Thayer 2010; 2017). Similarly, studies of Latin American "social motherhood" movements, such as the Madres de la Plaza de Mayo (Arditti 2009; Navarro 2001), have vividly shown that frustration, resignation, sadness, and anger mark the political organizing for los desaparecidos.

Rather than assuming that gender per se produces particular affects, or that any specific project (e.g., "social mothering," development politics, rights recognition) produces specific gendered affects, we extend feminist and gender scholarship by showing that the women in the 
study identified a history of gendered non-care as a key to how they felt about organizing for water. In foregrounding the experience of non-care, we privilege the interpretive frame that participants use, rather than seeking to read them directly from structural systems, forms of politics, or cultures that can only shape, but not define, interpretive possibilities. This stance emphasizes how women see themselves as political subjects—individually and relative to others — rather than their political effectiveness per se (Cossyleon 2018; Dernikos 2016; Kravetz 1978; Whittier 1995). It extends feminist scholarship and analyses of women's involvement in Latin American politics that show that the lens of whose lives deserve care, and whose are excluded, is central to the affective interpretations of political life (Berlant 2011; Harris 2018; Morrison, Johnston and Longhurst 2012; Puar 2009; Singleton and Mee 2017; Thayer 2010).

\section{Urban Clientelism and Survival Strategies under Structural Adjustment in Peru 1990-2000}

The mobilization for water emerged under structural adjustment in Peru during the 1990s, which played a role in the stories that women told about the meaning of their experiences in the water campaign. These policies shifted what citizens could expect from the government, and they coincided with changes in forms of political participation. Clientelism is no longer treated as "pathological" or as a singular process (Auyero, Lapegna and Poma 2009; Lapegna 2013; Oxhorn 2011). NGOs are now an increasing part of Latin American politics (Alvarez et al. 2017; Lind 2005; Thayer 2017), and the role of political parties is highly varied; in some places there is almost no party competition, in others voting is corrupt, and in still others, market-based influences have minimized the role of parties. Private firms now provide or co-provide social benefits, and they are also targets of political protests (Arce 2014). The increased heterogeneity of political forms 
reaffirms Alberto Melucci's (1996) observation that collective action cannot always be understood via the imposition of neat categorizations. These empirical and theoretical observations about heterogeneity and change are reflected in women's affective sensibilities about the experience of mobilizing for water, recalling a wide array of urban and rural Peruvian political forms in their stories, foregrounding their sense of suffering under all of them. The larger political circumstances to which they refer in their interviews and in the observations are thus key to understanding their affective worlds.

Material and Political Violence in the Countryside and City

Collective action in Peru, Paraguay, and Colombia, and in the Caribbean nations of Suriname, Guyana, and French Guiana, is comparatively understudied compared to other parts of Latin America. In Peru (as well as in Colombia) political violence involving the state, narcoterrorists, and armed insurgencies and terrorist organizations, have played a major role in shaping the existence, forms, and sensibilities of collective action projects (Arce 2008; 2015; Burt 2006; 2007; Blondet 2002). Moreover, while political parties exist on paper, they have been and continue to be overshadowed by one-party governance, established by President Alberto Fujimori (1990-2000). Civil society organizations were relatively weak during this period, and leftist politics were muted, with the exception of the Sendero Luminoso (Shining Path, SL) insurgency and similar rural, violent groups. Although clientelism existed in urban areas, collective action was strongly suppressed using violence and other means (Burt 2007).

After his election, Fujimori reversed his campaign promises and implemented a full structural adjustment program, including drastic cuts in social programs, including health care and 
education. The imposition of what became known as "Fujishock" also included new joint ventures between public and market-based entities, making firms, and not just government, a site of collective action politics. This situation is in contrast to the intermediate influence of parties that other analysts have shown is the case in other places (Álvarez Rivadulla 2012; Auyero 2000). The day after its implementation in 1990, prices in Peru more than tripled, plunging over half of the national population into poverty.

Establishing VES through Clientelism

The first generation of settlers arrived in VES in the early 1990s as part of a migration begun in the 1980s in which campesinxs sought to escape the SL insurgency, but grew dramatically with the imposition of structural adjustment policies under Fujimori. The migration began first in the Andean Department of Ayacucho, where the SL was highly active, and drove an estimated 600,000 people to Lima (White 2009, 44). Ayacuchanos made up a high proportion of the first settlers of VES, which became home to hundreds of thousands of the more than 600,000 internal migrants from that region, between 1980 and 2000 (White 2009). Several other of Lima's marginal city districts expanded rapidly as people fled the countryside, forming more than 27 new neighborhoods (Burt 1995, 282).

VES was established on the empty sand dunes that border the Pacific Ocean and form part of Peru's dry, desert coastline. Self-appointed dirigentes orchestrated what settlers call the invasión (invasion) of the open sands of the district. To claim land, people often arrived under the cover of darkness, and placed an estera, or straw mat, on the sand, erecting a makeshift roof if they had plastic sheeting. Dirigentes enforced the Peruvian government's rules for settlement: migrants 
had to be married, occupy the space for 24 hours a day, and attend all neighborhood meetings related to the solidification of the invasion into a recognized settlement. While there was intense political investment in maintaining control over kinship and physical presence, the government did not provide water or sanitation systems, nor any other infrastructural or social welfare benefits such as food, electricity, roads, schools, or clinics.

\section{Clientelist Survival Networks}

In 1992, more than 250,000 women in Lima alone resorted to taking part in survival organizations (Moser 2004, 219). The structure and politics of these organizations influenced how the campaign for water was organized, and came up frequently in the collective action stories of participants in the VES water campaign. During the late 1980s and 1990s, women participated in some 7,000 community kitchens (often operating in private homes) in order to feed their families. They prepared government rice, oil, and lentils for neighbors, in exchange for turning out public support for Fujimori at rallies and other events (Moser 2004, 219). Kitchens were vital for survival because most of Lima's nascent settlements were established by those escaping rural violence and poverty. Residents could not afford staple foods and few homes were equipped with kitchens. To receive food, each day a member of a family had to visit the kitchen in the morning, sign a ledger, and pay for the number of meals they needed. Typically, residents signed the ledger before 9:00 a.m. Residents returned to the kitchen each day at noon to claim their meals. Residents did not eat their

food at the kitchen; rather, they returned home to eat with their families, dividing up what they had purchased. Kitchens provided food from Monday to Friday. At the neighborhood level, coexisting with kitchens was the Vaso de Leche (Glass of Milk, VDL) program, in which the central 
government provided milk powder to each municipality in Lima for distribution to neighborhoods; municipalities only distributed milk powder to the neighborhoods that participated in rallies. The women who operated the kitchens soon organized them hierarchically, structuring them around the offices of president, secretary, and treasurer, establishing formal roles through which they brokered relationships with government food providers; the VDL brokers were less hierarchical (Rosa 2015, Sara 2017; Valeria 2017).

Before 1990, most community kitchens received aid from the Catholic Church, NGOs, and from some political parties. Progressive forces within the Catholic Church supported a strong coalition of community kitchens known as "Encuentro Nacional de Comedores" or the National Commission of Community Kitchens (CNC), who pressured the state for greater recognition and redistribution. In 1991, Congress signed Law 25307, which recognized the CNC's claims to food as a social right. However, Fujimori drew on the support from the military and dissolved Congress, by carrying out an autogolpe or self-coup (Levitsky 1999). Fujimori removed judges and formed a constituent assembly to draft a new constitution. When Fujimori closed Congress, the regime no longer honored Law 25307. One year later, his government created the Programa Nacional de Asistencia Alimentaria (National Food Aid Program, PRONAA), which took control of the distribution of international food aid, effectively weakening the power of the Catholic Church and the CNC (Rousseau 2009). As a result, the kitchen leaders, many of whom would go to lead the mobilization for water, were severely diminished in their political bargaining power, because this new form of national clientelism limited political competition (Rousseau 2006).

The internal dynamics of the kitchen and the milk programs were complex. They had access to material and political resources that other residents did not have but desperately needed. Some members of each VDL and kitchen formed what residents called comités centrales, or central 
commitees, inner circles that controlled the system. Since members of the comités centrales were paid by the government in food for their labor, they often attempted to extract favors from other neighbors because they wanted more compensation for their work.

These clientelist survival projects did not result in an expanded, nonviolent, civil society sector. Not only were such projects suppressed by the limited democracy under Fujimorismo and the state's war against the SL (Blondet 2002; Burt 2007; Degregori and Stern 2012; Dosh 2010), at the very local level, VES residents faced threats from SL. In 1992, SL militants murdered activist Maria Elena Moyano, who was a leader of both community kitchens and the VDL programs in VES. She was shot in front of her children, and then her body was dynamited. Residents interpreted her death as a clear warning against participation in popular organizing, a form that most already associated with the SL (Burt 2006; Moyano and Miloslavich Túpac 2000). ${ }^{1}$ The leadership of the VDL and kitchen programs shaped power asymmetries between residents as collective action for water later emerged. Brokers held on to positions of power, and extended national clientelist tactics that demanded participation in marches in exchange for material benefits. The women's stories of the water campaign refer to these political circumstances in their recollections and affective interpretations.

The Emergence of the Campaign for Water

Water was a perpetual problem from the beginning of the VES settlement. Located on a sandy desert, getting water to drink, cook, and clean homes and bodies was a constant struggle for residents in the 1990s. When Fujimori fled Peru in 2000, VES residents formed a coalition of neighborhood groups known as Consejo Directivo Multisectorial de Villa El Salvador 
(CODIMUVES, The Multisectoral Council of Villa el Salvador). Between 2002 and 2006, VES residents, alongside and separately from CODIMUVES, took part in a series of direct actions, ending in 2006 when the outgoing Alejandro Toledo government agreed to meet their demands. Following on this promise, the incoming García government implemented the Agua Para Todos program in 2007. Residents rejected the system that was offered, because they viewed the pipes as small and flimsy, based, in part, on having seen systems that were going into new buildings in wealthier neighborhoods where they worked as ambulantes, or street sellers. VES dirigentes took another approach in 2008, and began to negotiate with private firms and the state water company, Servicio de Agua Potable y Alcantarillado de Lima (SEDAPAL, Potable Water and Sewage Service of Lima), to provide water and sewer mains similar in quality to those in wealthier neighborhoods. Water and sewage main construction began in 2010 and finished in 2012. Using the often shoddy connections to homes, built by the residents themselves, the system delivers water of uneven quality at uneven speeds, and carries away sewage with equally varying efficiency. These political contexts are not in a simple sense causes of affective memories of the organizing experience; rather, we explain them here to provide a broader context for the specific interpretations that emerged in the interviews and observations.

\section{Methods: Interviews, Observations, and Situated Interviews}

Forms of Evidence, Language, and Authorship

Evidence for this study comes from three sources: interviews, participant observations, and centrally, "situated interviews." Author 1 carried out semi-structured, in-depth interviews with 42 
women and 6 men who settled VES between 1992 and 1994 and who described themselves as long-term participants in the movement for water services, and who said they have been involved in at least one direct action—strategic, clientelist political activity that included demonstrations and blockades (Moore and Woolley 2016). Interviewees also attended meetings and contributed funds.

Formal interviews took place in homes, community kitchens, childcare centers, and at local markets. Participants were asked questions about four topics: how they came to settle the neighborhood, how they came to participate in the collective actions for water, how the pipes got there, and how their lives had changed, if at all, as a result of the new water systems. Initial contacts were made by asking people at church, at markets, in community kitchens, and at school events who they saw as neighborhood leaders. Few answered that question directly, but named people who had been or were involved in neighborhood politics. The initial set of contacts were used to contact others; almost all of those identified initially and subsequently were women, ${ }^{2}$ and no interviewee felt that there were men who had been key leaders or especially active participants. Table 1 describes some of the social characteristics of these interviewees, qualities which are very similar to those who are not quoted. Most interviewees were mothers or grandmothers, and the few men, fathers. Almost all knew how to read and write, and were mainly from rural regions ${ }^{3}$ where the SL had been highly active, and/or where land concentration was taking place. Most women were between the ages of 40 and 60, had migrated from rural Peru, and worked in domestic service, as ambulantes or as homemakers.

Author 1 speaks Spanish fluently, and has been a part of the community for 17 years, beginning in 2002 as a student, then as a full-time volunteer in community kitchens and youth programs associated with the Catholic Church from 2003 to 2005. Between 2006 and 2008, Author 
1 was a volunteer in educational reform programs run by the community, and has been an academic researcher from 2010 to the present. These long-term community relationships build social ties that are likely to be different than those established over much shorter periods. As Black's (2010) study of the lives of three brothers over the course of 18 years shows, relationships of trust and taken-for-grantedness can emerge under these conditions. Similarly, "ethnographic returning," (O'Reilly 2012) or the routine revisiting of field sites over a period of years, can shift attention away from the researcher's role as researcher, and into one that is more ethically and epistemologically complex. In the VES case, the stories that people told frequently took for granted that Author 1, a white North American, was familiar with the struggle for water, the history of Peruvian politics, and could be trusted with stories that were sometimes demeaning or critical of other people. Interviewees may also have felt comfortable sharing their struggles because clergy who provide pastoral care but little in the way of material goods are among the most visible North Americans and Europeans in VES. Asking questions about the meaning of collective action projects can be understood by asking participants only about the collective action itself (or being ethnographically situated in it), or it can be understood by asking participants about it in relation to other aspects of their life. Adopting different methods allows for a conceptualization of social movement participation as a biographical "break" from routine politics and life that other scholars have emphasized (McAdam 1986; Pérez 2018; Polletta 2006) as only one of many ways that collective action projects shape the forms of subsequent social life.

Author 2 co-frames the arguments and interprets evidence in light of them. Author 2 speaks and reads Spanish, and has read and analyzed research articles and the original and translated interviews. 
Retrospective Interviews and Recall: Following the Pipe

Retrospective interviews are challenging to conduct in settings that are unrelated to the topics at hand, because they depend on recall methods generated by the interviewer. To address this issue, participant stories were gathered from “walking interviews" (Evans and Jones 2011; Pinsky 2015), in which Author 1 walked with participants along the water and sewage pipe lines in the neighborhood and at home, asking questions about how the pipes came to be there. Observations and interviews began two years after the mobilization ended. Yet no interviewee said that they could not remember details, and they were particularly forthcoming when walking along the pipes and in their own homes. Current social ties could have shaped how participants remembered the struggle for water. But rather than configuring that as a "bias" that does not get at the "pure" experience of mobilization, the interviews revealed that participants did not see those events as a particularly distinctive social time. Author 1's long-term engagement with the neighborhood also converges with the interviewee's recollections, which may be because many interviewees were known to the author. Since highly active members in the struggle (as identified by media and participants) were all interviewed, it is unlikely that the stories are purely a function of those ties.

We turn, next, to stories that the women told during the course of the interviews and observations, beginning with those they told about the politics and affects of settlement, and then follow with the very similar stories they told about the struggle for water. They refer to their own suffering, but not merely as a means of describing subjugation: they are telling stories of personal survival in this suffering, which demands sympathy. These affects - disaffection from community, and an insistence on care from Author 1-are consistent with what Ortner (1995) called 
"ethnographic refusal," in which those who are studied refuse neat categorizations. In this way, the interviews make the meaning of suffering itself more complex.

\section{Recalling the Settlement of VES: Forced and Fragile Family Lives}

Familial Fragility: Forced Marriages and Cama Adentro Work

Violence played a major role in the unprecedented movement of rural single women to Lima in the 1980s and 1990s (Alcalde 2010), and was vividly recalled by most of the participants in the campaign for water. Many stories were similar to Sara's: "I was 12 years old when I left my home. During that time there was terrorism in Peru, and in my village, people were being killed and women were being raped, that is why I came to Lima." Intact families rarely moved to Lima together; Sara and other women made the move without husbands or other kin, even if they had been married or were a parent, and many were quite young when they arrived. If they were single women, they almost always worked cama adentro. Literally, "bed inside," they were live-in cleaners, nannies, and cooks for families. While living with a family, they were in no way part of it: there was no established hourly wage, no limit on hours worked, and no formal contracts. Abuse, violence, and exploitation were common (Pérez and Llanos 2015), a set of relationships that was closely tied to gender and their limited social ties (Pérez and Llanos 2017). Women with children often reported that they first worked as ambulantes, a job that many have today. Many slept outdoors. Acquiring a space in VES offered the possibility of a home for these women. As they quickly realized, however, acquiring a home would pose major gendered kinship and work challenges. 
Because they had to be married in order to acquire a land title, many settlers, such as Beatriz, felt that they were forced to form families. She came to Lima at the age of 14, and two years later, heard about the invasion from a customer in the bakery where she had recently found work. Discovering that she could not make a claim unless she had a husband, she and Josué, whom she had recently met and faced the same problem as Beatriz - unable to claim a place in VES because he was single - were married. Beatriz (2016) explained how that moment had profoundly shaped her life:

The organizers made you have a spouse. I did not do it for love, I did it because I needed the land. I got together with him [Josué] because I did not have anything. I was living with a complete stranger. Little by little things happened and we had children. I wanted to study, and he would hit me and tell me my job was to stay at home and take care of the children. He eventually left me for another woman. I don't want anything like that to happen to my children, so I do everything possible for them to study and to give them food... I never had a childhood.

Other interviewees described a similar pattern:

When my first relationship ended, I came to VES with my two youngest children. But on my block, the dirigentes would not let single people stay, they were kicking out all the single people. In order to keep the land, you know what we did? We got together with the men to keep the land. I had to commit myself in that way. Many people do not know the actual story of what we had to commit ourselves to in order to stay. Other people do not want to admit it (Sonia 2017).

Beatriz clearly recalled her experience in individualistic terms, but Sonia's story at once appeals for collective sympathy_ "what we had to commit ourselves to"- - but disavows the possibility of sharing her experience with others who were married for reasons that had little to do with the religious and cultural meanings of the institution that would have been commonplace in rural Peru. But in both cases, their suffering is also expressed as worthy of sympathy. 
The settlement system was also recalled as corrupt. Pilar was one of the earliest settlers, and like Beatriz, she did not have a husband. Yet she convinced a dirigente to allow her to stay, in exchange for her unpaid labor:

When I arrived, they said that singles did not have any chance of staying because singles were not permitted to have land, only families. I did not have anyone, so I made myself useful. I got involved with the directorate, walking back and forth between the invasion and the municipality, taking attendance of the other settlers...I did not have money, but I worked to stay, until I became anemic. But what are you going to do?

As Pilar spoke, she held her head down, conveying a sense of shame or a need to hide in some way, and her sense of having no options_-participants frequently said, “Qué se va hacer?” or ¿Qué se puede hacer?” (What are you going to do?)—was a common theme across interviews, especially when interviewees reflected on formal rules and political arrangements. As we show later, other participants in the struggle for water assumed that corruption was rampant from the beginning of the settlement, emphasizing that dirigentes fostered what Montambeault and Goirand (2016) call the "individualization of political loyalties."

To keep the land claim, most women recalled, posed additional gendered family and work problems, because the government rules required that a settler had to remain in the invaded space at all times. Dirigentes or their proxies like Pilar could come at any moment and demand a signature from one of the land claimants. Dirigentes also took attendance at different hours of the morning, afternoon, and evening, and then again late at night. Because there were no markets or opportunities for employment close to the settlement, men, who had better employment options than women, spent most of their time working in Lima, while the women remained behind. Travel from the settlement to the center of the city and back was expensive and not dependable, which meant that men often would spend days away, and over time, many of the men abandoned their nascent families. 
When Josué left the family, Beatriz's material situation became even more desperate:

He would leave us hungry. Once, on a Saturday he never came back from work. Not on Sunday. Not on Monday, either. So, we went to the market and the woman who feeds the pigs had left out tomatoes and potatoes. I took them. And that is what we ate with a little wheat that I had. Over time, my anger just kept building. I asked God for the water, I needed something to make things easier. I would have given up food to have it.

As with the other stories of settling, what Beatriz describes here is not the collective suffering of her neighbors, but just her own, despite the common problems of water scarcity, family fragility, and economic precarity. This story is at once of personal suffering and of dignity, too; being angry at her situation, and expressing how deeply motivated she was to find some way to survive.

Water and Bare Life

The difficulties imposed by these arrangements—quick and instrumental marriages, social and economic abandonment by partners in an unequal labor market, and a corrupted system of land distribution-coexisted with an increasingly dire water situation: Beatriz described her house as "full of flies," and that her roof was made of "thin plastic sheets and there was no bathroom." She and other residents stood outside waiting for water trucks when they could, often after a "head count" by brokers had taken place.

Yet no one recalled these instances as moments of social bonding. Residents never knew when trucks would arrive, and prices fluctuated. On many occasions, participants described the dirty water and the dangers it posed to them and their families' health: "The trucks were old, and the water was dirty, it had worms in it. When I washed my face, I could feel them on me. You had to boil it well if you wanted to use it." Catalina burst into tears as she told the story, and expressed 
her shame at having to carry buckets of water uphill over slippery sand when the trucks did bring water: "It was so embarrassing, I had to carry paint cans of water!" Similarly, another interviewee, Daniela (2016), using a broom to brush away the sand on top of the cement slab covering the water meter that connected the pipes in her home to the central water line, explained what life was like for her (but not her neighbors) when water was scarce—and her resentment at having to participate in the collective action project:

The trucks [government and private sector] always delivered dirty water. I used to put it in a small bucket and mix it with bleach. And the men, they don't know, all they say is hello and goodbye. But I had to live with all the bad, I had to go through all of it. I dug the holes [at the back of her property] for the latrines and worried about the babies. I was embarrassed. I felt shame.

Still, her dignity remains intact, for she places her feelings of shame and embarrassment in the past, situating herself as having lived through a particularly undignified moment.

Others emphasized that the water situation intensified the difficulties of migration and material poverty. Among the most common and vivid of these stories were those that described their personal difficulties in raising children without water, tying their struggles to intimate kin, not to children more generally. As one participant explained, "As a woman, I did the cooking and cleaning, so I was most concerned about the water. When you have small children, they do not understand that there is no breakfast without water, they just understand their hunger" (Olguita 2015).

To address the failure of the trucks to deliver water, in small groups or alone, women went to other neighborhoods to try to convince water trucks to come to their neighborhood. This often came at the expense of other blocks, who were still waiting for water, and it was thus a source of conflict. Because water was expensive and scarce, if they did not safeguard their water, which they usually stored outside their homes, it would disappear during the night. "It was awful. The trucks 
did not come often, and thieves were constantly stealing water. They would take the entire barrel, all of it!" (Pilar, 2016). Most blamed their neighbors for these thefts.

Although the Peruvian government played no role at this point in helping to establish a water system, international NGOs attempted to assuage the water situation in the late 1990s. They hastily built poorly run systems that ultimately broke down, politically and socially. One participant, Pilar, recalled that "the water was dirty and scarce, and the only help we received came from those foreigners...I think they were called UNICEVES? I don't know, but they gave us pills for the water" (Pilar 2016). The water tablet project was sponsored by UNICEF, and was taken over by a short-lived European Union-sponsored water distribution program known as Project Alas, both of which provided communal water pumps and hoses. The program lasted less than a year. The failure of the state or NGOs to provide aid gave further evidence of abandonment — and of the willingness of residents to exploit their neighbors:

We had that project that the Europeans created for us. One neighbor was supposed to go from house to house with the hose and fill up everyone's buckets. You still had to pay for the water and the price depended on the person in charge of the hose for that day. The price fluctuated and at times it was 2 soles a bucket, which was very expensive in those days. However, it all fell apart because we couldn't agree on pricing. Whoever was responsible for the hose didn't always come. It was a disaster! (Jimena 2016).

Several other participants mentioned the EU program as an example of how they were unable to work together because there was "no unity." According to Elena (2017),

The European Union gave us this water project supposedly through an agreement with the government. I don't know. It was that green tower up there, see it? The dirigentes were in charge of it. But only one person had a key to the water tank and controlled the hose. You had to pay, but the dirigentes never said where the money was going or what it was for. Eventually the person in charge stopped coming or only when they could get paid, which was not very often. No one took charge and the whole thing fell apart and it got rusty. Such a waste of money! 
These experiences also support what Lind (2005) found in Ecuador: when foreign aid fills in the spaces where the state fails to address, the poor are expected to work for free, which broadly erodes community relationships. Elena and Jimena's description of the NGO water project richly describe its failures, but there is no equally rich language to describe the collective suffering that the project brought to the neighborhood.

Families were also running out of space for human waste, which they had been placing in nine-foot holes or "silos" that they dug at the back of their homes. When the holes filled, they were topped off with lime and cement, and another hole was dug. The silos began leaking through the sand. Late at night, desperate residents would dump waste in front of others' homes and on the street, causing hostility among residents:

It was horrible, you know? The silos did not last long, and we [in the context of the interview, she is describing her family suffering] had lived like that for more than ten years. The neighborhood was surrounded by silos, everywhere you looked. That is why our [she and her husband's] children became so sick with stomach problems. People would leave bags of it out at night on the corners, in front of other people's homes (Nelly 2015).

These recollections of personal suffering and of mistrust stand in sharp contrast to Lomnitz's (1977) classic study of the power of survival networks in urban settlements in Mexico, and Párraguez Sanchez's (2012) study of urban residents' collective protection of their neighborhood from encroaching developers in Chile. In both of those cases, however, organizers and participants were part of well-established communities where social ties were robust.

These stories of the feeling of life before the water campaign, in which the participants heighten their own suffering and insist on sympathy and dignity at the same time, were paralleled in their stories of the campaign for water in VES.

\section{Personal Suffering and Bare Bonding in the Organizing Process}


Collective action projects can reorganize affective life, shifting the focus from the sense that problems are individualized to the sense that they are the product of shared broad causes that can be socially, legally, and materially remedied by the efforts of working together. But few who participated in the project recalled it in a way that made it especially distinct from their social and material lives with limited water and fragile family life. Their own sadness, anger, resignation, and alienation from others was at the center of their recollections, even when they described collective activities and actions.

\section{Organizing as a Financial and Temporal Struggle}

The methods that dirigentes (often drawn from the community kitchens and VDL programs) used to recruit and retain participants extended the pattern of exchange that had been established in the invasion and in the delivery of food and milk. Dirigentes imposed high fines on those who did not attend meetings or marches. If residents missed events and refused to pay the fines, dirigentes put them on a list, and informed them they would not receive water and sewage services. According to participants, each household was also required to contribute money to a general fund to cover expenses associated with neighborhood marches, meetings with state authorities, and bus fares for leaders. Attendance was taken at the onset and conclusion of all actions.

Whereas some scholars of social movement leadership have shown that leaders' "social capital" - their knowledge of social ties and community culture — shapes their capacity to appeal to multiple constituencies and address internal strife (Nepstad and Bob 2006), there is little sign that dirigentes sought to create a sense of solidarity among participants. Instead, they operated in 
a way that is tied closely to Mancur Olson's (1965) assertion that collective action is generated by selective incentives and punishments. Several decades of scholarship have shown that not all forms of collective action involve the problem of coercing people into participating or providing positive selective incentives, nor do they involve the purely cognitive calculations that Olson emphasized. The qualities and processes Olson describe are thus not universal, but they do characterize participants' recollections of life before, during, and after the struggle for water, for reasons that we turn to next.

Uniformly, participants recalled participation as personally onerous: "We marched for years with our signs, to the Ministry and Congress. It was very dangerous. The police came after us and we ran. But what are you going to do? I needed the water and if I didn't go, I wouldn't get the water, or I would have to pay a fine" (Hayde 2016). Thalia, a participant who had begun to work in a factory to support her three children after having run an (uncompensated) VDL program from her home, describes having to decide between missing work and attending the various marches and meetings that leaders arranged. Like Hayde, she describes collective experiences, but only her own affective life in regard to them: “The dirigentes fined you 50 soles if you didn't go...you are fighting for your wellbeing because water is life, you can't live without water. What else could I do? I had to go!” This sense of inevitability was expressed in a loud and defiant voice; Thalia felt she had no choice, but also maintained a sense of outrage over the experience. The same tone was used by Melinda, who recalled that "When the leaders came and asked for our quota, I paid it, what else could I say to her? She told me to think of my children and so I paid it. I had to work longer hours, but I paid it” (Melinda 2015).

Resentment at Men's Nonparticipation 
Not only did most participants resent organizing and fines, they were angry that men from VES did not participate. Roxana, a long-time participant, recalled the intensity of required participation and her pessimistic view of the likely results:

They always passed a list around. They took attendance before and after the march. And I was skeptical, and the others were too. We kept saying, 'March? Why march if nothing will change? It will be a waste of time.' But we went because they said we wouldn't get water and it was terrible. The tear gas got in your eyes, wow, how I cried. And I was scared. I had my son with me who was only three months old. I was afraid for his eyes and so we ran. And they used those tanks that shoot water. So, we ran some more. That is what I did. I fought for the water, not the father of my children. He wasn't there.

After her description of the events, and the sense of pessimism that many felt, Roxana quickly turns attention to the pain in her own eyes, and then mentions her son before describing how the group was fired upon by water tanks. In disavowing her husband's role and failing to note the harms that came to others, she makes the suffering her own, and calls upon the listener to see her actions as morally worthy.

Even among couples who had been together for a long time, women insisted that they be recognized for their participation and sacrifices. Diana and Henri, who were among the first families to settle in VES in 1992, migrated from San Martin in northern Peru with their children to get away from the war between the SL and the government. While Diana was explaining her involvement in the marches for water, Henri entered the room. He interjected and spoke over Diana's recollections about the marches. Diana tensed up and her face became serious. She compared participating in the marches to being part of a census, given the way that the dirigentes took attendance. ${ }^{4}$ Henri added that it was the only way to get everyone to participate. When Henri's phone rang, he left the room, and Diana turned, lowered her voice, and said "Don't listen to him. He wasn't there, I was at all the marches, I took care of my children. I suffered.” 
Fear on the Highway

Physical dangers - tear gas, fire hoses, among others - were a common recollection for many participants. But above all, the risks involved in blocking the Pan-American Highway (PAH) were especially vivid for participants. While many marches were tolerated by the state, demonstrating in front of the presidential palace was strictly prohibited, and blocking the PAH, the only major route connecting Lima to the north and south, was a common site of protests, but usually quickly suppressed by the police. Pilar described such an event:

There were always meetings, assemblies at night, constantly. The directorate discussed the marches and plans. We blocked the Pan-American [highway], we all had to go, we had to fight. We were down by the beach [on the highway]. It is against the law to block the road there, you know. That time, the dirigentes had convened a huge group of people to block to road. The police came and there was a clash between us and them. They began to shoot tear gas at us. One of the canisters hit me here on the shoulder and caused an open wound. The news showed up, that was the only way we can get the authorities to see what we needed. Maybe something came of it. I don't know. That was one march I remember clearly other than the constant assemblies. Constant.

Resignation, personal injury and the relentlessness of the meetings are at the forefront of the narrative, much as they were for Roxana. None of the participants, however, described a sense that the risks were part of a collective decision-making process, and recalled the methods used as "negative incentives" that had the most deleterious effects on their own bodies and spirits.

Mistrust in Dirigentes, Dirigentes' Disaffection from Clients

Unlike some other forms of clientelism in which there is affection for brokers (Auyero and Benzecry 2017), participants often reported deep mistrust of them in the water campaign, and 
brokers felt that they were unfairly under suspicion from participants. Between the time the settlement emerged and when it finally received water, dirigentes turned over several times. Participants believed that dirigentes stole money from the community, or failed to deliver on promises. Gladys' interpretation was typical:

One time when I was at one of the community meetings with my neighbors, we were talking while the neighborhood dirigente was addressing us and one of my neighbors said: "The day that they give us our title, lights and water, then they can all go to the devil. Once I have all that, I will have no need for these meetings! The Secretary General? Ha! You pay your bills, and everyone goes their own way, the Secretary General can go to the devil, what good does she do? All she does is eat our money."

These experiences were similar to those told about the early organization of the kitchens and the VDL program. According to Valeria (2017), originally, each woman who worked at the kitchen was supposed to take a turn as president, secretary, and treasurer. However, the system did not function according to plan: "It was never that transparent. People would make accusations and money would go missing. People are terrible, how they talk. Eventually, many of the women left the association and Rosa remained until she became Secretary General.” Similarly, Gladys (2016), evoking Junge's (2014) observations about envy and collective action, said that "I worked in the kitchen for a while, when I was really needy. But what exists there, in any kitchen really, is jealousy, envy, and the sense that one is out for themselves. Not sharing."

Dirigentes were deeply aware of the hostility that their methods generated, and puzzled over it. They saw themselves as working hard and taking many risks, and thus worthy of respect that was never forthcoming. Rosa, for example, found her work for water difficult, and was saddened by the lack of approbation from participants:

This was my first experience as Secretary General [of VES] and it was a very strong experience and it made me cry sometimes but not because of what you think, it was my own neighbors that made me cry and when the water finally came, I felt two things: joy and indignation because my neighbors would always say to me in the 
streets: "Hey when is the water coming?" or "It has been a long time, what are you doing?" And they accused me of not paying for my water and I did, stupid or not, like everyone else.

Other dirigentes were also aware of these sentiments, and they resented the suggestion that they were not transparent, nor did they feel respected. Marta, the treasurer for the neighborhood mobilization, endured insults and gossip by her neighbors, who suggested that she was taking group funds for her own personal benefit. Those feelings remained well after the movement ended: "I just avoid going to certain parts of the neighborhood now, I don't have to hear what people are saying. And besides, I prefer to spend time with my children in my home." Barely bonded to others in her area, her language of active choice to spend time with kin suggests that the hostility had not ruined her.

Marta and Rosa offer slightly different valences with respect to the sense of being barely bonded. In the first, Rosa experienced this hostility as something shared among neighbors, and many interviews support her interpretation. Her feeling could thus be interpreted to mean that neighbors were indeed bonded over their anger at her. But given that there were perceptions of corruption, and that few participants referred to others' affective lives, Rosa's feelings might also be understood as a component of a larger web of non-affections that existed during the mobilization. Marta's experience both resonates with Gladys', and it reinforces patterns of storytelling by participants, in which rich affective description is used to capture personal suffering worthy of sympathy.

\section{“Cada Uno Por Su Lado": Each Person Goes Their Own Way}


Political victories such as the acquisition of a water and sewage system might be expected leave in place some form of solidarity in the end. Yet participants in the fight for water did not report such feelings, nor was a stable clientelist system in place. Eventually, SEDAPAL, the government water utility, working with private firms, built the water mains in VES, costing households $\$ 2,500$; many took out high-interest loans to cover this cost. The pipes to and from the house, the indoor fixtures, and their maintenance were the responsibility of households. No collective maintenance systems emerged, and many people used the phrase "cada uno por su lado" (each person goes their own way) to describe life after the mobilization. This became particularly apparent when they discussed where the main water line connected to their homes. As Pilar followed her own pipe, she explained that the initial work was shoddy, and that she mistrusted the neighbor whom she had hired to help with a leak.

Here is where the construction company placed the pipe, but here it stops, this is where you had to do it yourself. But since I am alone, and don't know anything about these things, the sewage pipe seemed to be leaking from the construction company out front. I paid my neighbor 50 soles to connect it for me. You know, Arturo who lives on the other side there? He did a bad job, see where it leaks there? When he installed it, he needed a ladder for the shower, so he brought his, but he forgot it. He never finished the job! Now when he asks about the ladder, I tell him he cannot have it back until he fixes my leak. He still hasn't fixed the leak. [She continued to walk along the pipes]. Here is where the pipe runs through the house to the back. But I could only run one faucet, that is all I had. Like I said, I lived with very little. Mostly I make just enough to feed my kids. I have plenty of space, I just cannot afford the pipes. The father of my kids is an irresponsible man. He only gives me money when he feels like it.

The same affects, and the same style of storytelling remain visible: a description of events common to many, and her own particular suffering and her sense of her moral worthy as a person. Other participants found the neighborhood unfriendly: "You would think that people do not live here, sometimes they walk by and greet you and sometimes they act as though you are not there" (Paloma 2016). Participants' neighbors recalled the good that the water mobilization had done, but 
for Catalina, this came with no specific appreciation of her sacrifices, and with the knowledge that having a water system did not result in an effective neighborhood political system:

I lived the marches, the violence, all of it. This is the house where I will live for the rest of my life. I am not like those who sat by with their arms crossed. Sometimes you hear them say, "The fight for water was so important." And I say, $I$ was there, but YOU ALL watched from your doors. All that I have is because of my own effort. Today there is no unity in the neighborhood. And now you can really tell how things are by how the dirigentes are absent from our lives now.

Like other interviewees, she expressed no sense of sympathy, care, or concern for neighbors, nor anticipated that they would be forthcoming from others, either.

While the community kitchen continued to be a place where neighbors interacted, encounters remained perfunctory and individualized: "I have always worked in the kitchen, washing, cleaning, in exchange for water and food" (Andrea 2016). Andrea and others like her were able to work their water debt off to Rosa at the community kitchen. And while Beatriz was president in name, Rosa remained the final authority of the kitchen. Rosa saw the operations of the kitchen in a similar light to other neighborhood associations, "People just want to go there and consume. Each person just goes their own way." It is critical to note, however, that the bare bonding was civic in nature: many did express joy and happiness when talking about their children, and when they were at children's birthday parties, they were clearly happy to see their children enjoying themselves, but interacted minimally with other adults, thus further complicating the narratives of suffering that were a central theme in participants' discussion of their lives and the political mobilization for water.

\section{Bare Bonding: The Affective Politics of Gendered Non-Care and Collective Action}


The women in VES interpreted their participation in the long struggle for water as continuous with their struggles for survival in other political circumstances that they saw as specific to their own lives. The political actions they undertook were not, for them, a special type of political life, where senses of power and solidarity were formed and the violence and threats from the state were unusual. As Arce (2008) and others have shown, in Peru, the forms that politics take shift and change, such that analytic distinctions, such as clientelism, social movements, left wing militarism, neoliberalism, democracy and developmentalism, were not foregrounded in their stories. What was affectively salient to them was that to acquire water systems that were essential to health and life, they had little choice but to act under the direction of dirigentes who extracted payments and took attendance and were suspected of being dishonest. That they shared experiences with other women did not mean that they felt solidarity with them. Yet they also insisted that they be seen not as victims, but as people who have personally survived with little assistance from other individuals (including most men) and larger political systems (such as UNICEF, public-private partnerships, and governments) for whom sympathy from the ethnographer is warranted. The materially fragile and temperamental water systems that needed individual tending reflect these mixed affective senses of having won something but at continuing cost. The long-term relationship of Author 1 to the community, in which they may have seen him as a person who had long cared for them and who might be associated with the Catholic Church, likely shaped their expectations of being recognized.

More broadly, these affective interpretations extend scholarship based on USA/EU models of collective action, which have tended to focus on affect as something distinct from cognition, and have understood the feeling worlds of collective action in the context of liberal democracies with long-standing political institutions, including, in the USA, civic associationalism. These 
freedoms of association and senses of stability are reflected in some of the rationalist frameworks of how affective experiences shape participant's choices about how to interpret and act on collective action experiences (Gould 2009; Goodwin, Jasper and Polletta 2002; McAdam 2006; Whittier 1995). Latin American perspectives that seek to characterize politics in the region draw attention to the importance of attending to specifically Latin American experiences of factors not formally recognized as politics per se, such as religious systems (Junge 2014; Nepstad 2004) and the use of violence (Gay 2012; Penglase 2009), despite their regularized use. Many analysts of the political structures in the region have described unstable forms of politics and collective action, especially in the Andean region (Alvarez et al. 2017; Álvarez Rivadulla 2017; Arce 2015; Arias and Goldstein 2010; Auyero and Benzecry 2017; Hanson 2018; Hanson and Lapegna 2018; Lapegna and Auyero 2012; Lazar 2008; Silva 2016). The participants in the campaign for water clearly experienced these shifts and changes not as opportunities or as roads to more democratic futures, but as an array of systems of non-care against which they had to struggle to meet material needs that other writers (Álvarez Rivadulla 2012; Perry 2013 ) have shown to be so critical in the region, in part because of neoliberal politics (Bair and Hough 2012; Lind 2005; Neumann 2013). Seeing politics from specific sites in Latin America thus illuminates both a wider range of possible sources of affective political life, and it draws attention to the affective consequences of long-term and widespread political violence and suffering, even in the face of hard-won material collective action victories.

Social and representational citizenship experiences are not identical in any political territory. In the case of the struggle for water, the sense of not mattering to others, a politics of non-care, extends feminist and gendered understandings of collective action projects in Latin America and of neoliberal politics of abandonment (Berlant 2011; Puar 2009) more generally. 
First, the capacity to get water reaffirms the power of women as political organizers and their capacity to maintain kinships and acquire rights and material goods through collective action projects (Harris 2018; Perry 2013; Richards 2005). Second, the sense of non-care, even in the face of material success, was interpreted as specifically gendered: they asserted that while they were organizing they had little assistance in caring for family members, the work worlds that were available to them were sometimes dangerous and paid very little, and the organizing systems were masculinized in the sense that caretaking was not built into meetings or other events which resulted in increased material and affective burdens.

These feelings of care and non-care are essential to what politics means: who might be counted on, who can be sacrificed, and whose needs can be ignored (Berlant 2011; Harris 2018; Morrison, Johnston and Longhurst 2012; Puar 2009; Singleton and Mee 2017). That the long campaign for water in VES extended the feeling of being barely bonded is underscored by how women recalled forms of political action in collective terms, while also using individualistic language to describe affective experiences that revealed a sense of non-care. Told this way, our analysis enables a richer view of how community and individual biographies are shaped by collective action, one that does not include a sense of progress, optimism, or solidarity, but one in which the politics of non-care, and efforts at maintaining dignity, are ongoing experiences. 


\section{References}

Abu-Lughod, Lila. 1990. The romance of resistance: Tracing transformations of power through Bedouin women. American Ethnologist 17 (1) 41-55.

Alcalde, Cristina M. 2010. The woman in the violence: Gender, poverty, and resistance in Peru. Nashville: Vanderbilt University Press.

Alvarez, Sonia E. Jeffrey W. Rubin, Millie Thayer, Gianpaolo Baiocchi, and Agustín Laó-Montes. 2017. Interrogating the civil society agenda: Reassessing uncivic political activism. In Beyond civil society: Activism, participation, and protest in Latin America, ed. Sonia E. Alvarez, Jeffrey W. Rubin, Millie Thayer, Gianpaolo Baiocchi, and Agustín Laó-Montes, 1-24. Durham: Duke University Press.

Álvarez Rivadulla, María José. 2012. Las invasiones de tierras y la izquierda en la ciudad:

Montevideo, Uruguay, 1984-2011. Revista de Ciencia Política 32 (2): 411-431.

Álvarez Rivadulla, María José. 2017. The weakness of symbolic boundaries: Handling exclusion among Montevideo's squatters. International Journal of Urban and Regional Research 41 (2): 251-265.

Arce, Moises. 2008. The repoliticization of collective action after neoliberalism in Peru. Latin American Politics and Society 50 (3): 37-62. 
Arce, Moises. 2014. Resource extraction and protest in Peru. Pittsburgh: University of Pittsburgh Press.

Arce, Moises. 2015. Protest and social movements in Peru. In Handbook of social movements across Latin America. eds. Paul Almeida and Alan Cordero Ulate, 275-289. Dordrecht: Spring Science Business Media.

Arditti, Rita. 1999. Searching for life: The grandmothers of the Plaza De Mayo and the disappeared children of Argentina. Berkeley: University of California Press.

Arias, Enrique Desmond and Daniel M. Goldstein. 2010. Violent Pluralism: Understanding the New Democracies of Latin America. Violent Democracies in Latin America, eds. Enrique Desmond Arias and Daniel M. Goldstein, 1-34. Duke University Press.

Auyero, Javier. 2000. Poor people's politics: Peronist survival networks and the legacy of Evita. Durham: Duke University Press.

Auyero, Javier. 2003. Contentious lives: Two Argentine women, two protests and the quest for recognition. Durham: Duke University Press.

Auyero, Javier, Pablo Lapegna, and Fernanda Page Poma. 2009. Patronage politics and contentious collective action: A recursive relationship. Latin American Politics and Society $51(3): 1-31$.

Auyero, Javier, and Débora Alejandra Swistun. 2009. Flammable: Environmental suffering in an Argentine shantytown. Oxford University Press.

Auyero, Javier, and Claudio Benzecry. 2017. The practical logic of political domination: Conceptualizing the clientelist habitus. Sociological Theory 35 (3): 179-199.

Baiocchi, Gianpaolo and Lisa Corrado. 2010. The politics of the habitus: Publics, politics and race in Brazil. Qualitative Sociology 33 (3): 369-388. 
Bair, Jennifer and Phillip Hough. 2012. The legacies of partial possession: From agrarian struggle to neoliberal restructuring in Mexico and Colombia. International Journal of Comparative Sociology 53 (5-6): 345-366.

Bayón, María Cristina and Gonzalo A. Saraví 2019. Desigualdades: Subjetividad, otredad y convivencia social en Latinoamérica. Desacatos 59: 8-15.

Bebbington, Anthony, ed. 2012. Social conflict, economic development and extractive industry: Evidence from South America. London: Routledge.

Bebbington, Anthony, Denise Bebbington, Jeffrey Bury, Jeannet Lingan, Juan Muñoz, and Martin Scurrah. 2008. Mining and social movements: Struggles over livelihood and rural territorial development in the Andes. World Development 36 (12): 2888-2905.

Bennett, Elizabeth A., Alissa Cordner, Peter Taylor Klein, Stephanie Savell, and Gianpaolo Baiocchi. 2013. Disavowing politics: Civic engagement in an era of political skepticism. American Journal of Sociology 119 (2): 518-548.

Berlant, Lauren. 2011. A properly political concept of love: Three approaches in ten pages. Cultural Anthropology 26 (4): 683-691.

Black, Tim. 2010. When a heart turns rock solid: The lives of three Puerto Rican brothers on and off the streets. New York: Pantheon Books.

Blondet, Cecelia. 2002. The 'devil's deal': Women's political participation and authoritarianism in Peru. In. Gender justice, development, and rights, eds. Maxine Molyneux and Shahra Razavi, 277-305. New York: Oxford University Press.

Burt, Jo-Marie. 1995. Shining Path and the decisive battle in Lima's barriadas: The case of Villa el Salvador. In. Shining and other paths: War and society in Peru, 1980-1995, ed. Steve Stern 267-306. Durham: Duke University Press. 
Burt, Jo-Marie. 2006. Quien habla es terrorista: The political use of fear in Fujimori's Peru. Latin American Research Review 4 (3): 32-62.

Burt, Jo-Marie. 2007. Political violence and the authoritarian state in Peru: Silencing civil society. New York: Palgrave Macmillan.

Carrión, Julio, Patricia Zárate, and Mitchell Seligson. 2012. Political culture of democracy in Peru and in the Americas, 2012: Towards equality of opportunity. http://www.vanderbilt.edu/lapop/peru/Peru_Country_Report_2012_English_W.pdf accessed April 15, 2019.

Chisholm, Jennifer. May 31, 2018. Vulnerability talk: Justifying women leaders in the favela housing rights movement in Rio de Janeiro. Talk given at the Conference on Emotional Politics, University of Kent.

Cohen-Cole, Jamie. 2016. The open mind: Cold War politics and the science of human nature. Chicago: The University of Chicago Press.

Combes, Hélène. 2018. Local politics and a self-assessment of political practice. Perspectives of a neighborhood leader in Mexico City on their political trajectory. Íconos, 22(60): 31-56.

Copeland, Nicholas. 2014. Mayan imaginaries of democracy: Interactive sovereignties and political affect in post-revolutionary Guatemala. American Ethnologist 41(2): 305-319.

Cossyleon, Jennifer Elena. 2018. 'Coming out of my shell': Motherleaders contesting fear, vulnerability and despair through family-focused political organizing. Socius, March 20. https://doi.org/10.1177/2378023117734729.

Degregori, Carlos Iván, and Steve J. Stern. 2012. How difficult it is to be God: Shining Path's politics of war in Peru, 1980-1999. Madison: The University of Wisconsin Press.

Dernikos, Bessie P. 2016. 'Queering' \#BlackLivesMatter: Unpredictable intimacies and political 
affects. SQS Journal 1-2: 46-56.

Dietz, Henry. 1998. Urban poverty, political participation, and the state: Lima, 1970-1990.

Pittsburgh: University of Pittsburgh Press.

Di Marco, Graciela. 2017. Social movement demands in Argentina and the constitution of a feminist people? In Beyond civil society: Activism, participation, and protest in Latin America, eds. Sonia E. Alvarez, Jeffrey W. Rubin, Millie Thayer, Gianpaolo Baiocchi, and Agustín Laó-Montes, 141-155. Durham: Duke University Press.

Dosh, Paul. 2010. Demanding the land: Urban popular movements in Peru and Ecuador, 19902005. University Park: The Pennsylvania State University Press.

Evans, James and Phil Jones. 2011. The walking interview: Methodology, mobility and place. Applied Geography 31 (2): 849-858.

Fanon, Frantz. 1963. The Wretched of the earth. New York: Grove.

Fernández Kelly, Patricia and Jon Shefner, eds. 2010. Out of the shadows: Political action and the informal economy in Latin America. University Park: Penn State University Press.

Freire, Paulo. 1970. Pedagogy of the oppressed. New York: Herder and Herder.

Gay, Robert. 2012. Clientelism, democracy, and violence in Rio de Janeiro. In Clientelism in everyday Latin American politics, ed. Tina Hilgers, 81-98. New York: Palgrave Macmillan.

Goodwin, Jeff, Jasper, James M. and Francesca Polletta. 2001. Passionate politics: Emotions and social movements. Chicago: The University of Chicago Press.

Gould, Deborah. 2009. Moving politics: Emotions and ACT UP's fight against AIDS. Chicago: The University of Chicago Press.

Gravante, Tommaso and Alice Poma. 2018. Manejo emocional y acción colectiva: 
Las emociones en la arena de la lucha política. Estudios Sociológicos 108: 595-618.

Hanson, Rebecca. 2018. Deepening distrust: Why participatory experiments are not always good for democracy. The Sociological Quarterly 59 (1): 145-167.

Hanson, Rebecca and Anthony Lapegna. 2018. "Popular participation and governance in Kirchner's Argentina and Chávez's Venezuela: Recognition, incorporation and supportive mobilisation. Journal of Latin American Studies 50 (1): 153-182.

Harris, Angelique. 2018. Emotions, feelings, and social change: Love, anger, and solidarity in Black women's AIDS activism. Women, Gender, and Families of Color 6 (2): 181-201.

Hilgers, Tina. 2012. Democratic Processes, clientelistic relationships, and the material goods problem. In Clientelism in everyday Latin American politics. ed. Tina Hilgers, 3-24. New York: Palgrave Macmillan.

Holston, James. 2009. Insurgent citizenship in an era of global urban peripheries. City \& Society 21 (2): 245-267.

Hurtado, Edison. 2014. Actores, escenarios y tiempos: Algunos desafíos para estudiar la acción colectiva en colonias populares. eds. María Luisa Tarrés Barraza, Laura B. Montes de Oca Barrera and Diana A. Silva Londoño, Arenas de conflicto y experiencias colectivas. Horizontes utópicos y dominación, 297-349. México: El Colegio de México.

Jaquette, Jane S. 2009. Feminist agendas and democracy in Latin America. Durham: Duke University Press.

Jasper, James. 1998. The emotions of protest: Affective and reactive emotions in and around social movements. Sociological Forum 13 (3): 397-424

Junge, Benjamin. 2014. The energy of others: Narratives of envy and purification among 
former grassroots community leaders in Porto Alegre, Brazil. Latin American Research Review 49: 81-98.

Junge, Benjamin. 2017. Uncivil subjects, uncivil women: Civic participation, ambivalence, and political subjectivity among grassroots community leaders in Porte Alegre, Brazil. In Beyond civil society: Activism, participation, and protest in Latin America, eds. Sonia E. Alvarez, Jeffrey W. Rubin, Millie Thayer, Gianpaolo Baiocchi, and Agustín LaóMontes, 81-100. Durham: Duke University Press.

Kleres, Jochen, and Åsa Wettergren. 2017. Fear, hope, anger, and guilt in climate activism. Social Movement Studies 16 (5): 507-519.

Kravetz, Diane. 1978. Consciousness-Raising Groups in the 1970's. Psychology of Women Quarterly (3) 2: 168-186.

Lapegna, Pablo and Javier Auyero. 2012. Democratic processes, patronage politics, and contentious collective action in El Alto Bolivia. In Clientelism in Everyday Latin American Politics, ed. Tin Hilgers, 63-80. New York: Palgrave Macmillan.

Lapegna, Pablo. 2013. Social movements and patronage politics: Processes of demobilization and dual pressure. Sociological Forum 28 (4): 842-863.

Lazar, Sian. 2008. El Alto, rebel city: Self and citizenship in Andean Bolivia. Durham: Duke University Press.

Le Bon, Gustave. 1977. The crowd: A study of the popular mind. New York: Penguin Books. Levine, Daniel H. and Catalina Romero. 2010. Urban movements and disempowerment in Perú and Venezuela/ Movimientos urbanos y desempoderamiento en Perú y Venezuela. América Latina Hoy 36: 47-77.

Levitsky, Steven. 1999. Fujimori and post-party politics in Peru. Journal of Democracy. 10 (3): 
78-92.

Lind, Amy. 1997. Gender, development and urban social change: Women's community action in global cities. World Development 25 (8): 1205-223.

Lind, Amy. 2005. Gendered paradoxes: Women's movements, state restructuring, and global development in Ecuador. University Park: Pennsylvania State University Press.

Lomnitz, Larissa. 1977. Networks and marginality: Life in a Mexican shantytown. Academic Press.

McAdam Doug. 1982. Political process and the development of black insurgency, 19301970. Chicago: The University of Chicago Press.

McAdam Doug. 1986. Freedom summer. New York: Oxford University Press.

Melucci, Alberto. 1996. Challenging codes: Collective action in the information age. Cambridge University Press.

Molyneux, Maxine. 2008. The 'neoliberal turn' and the new social policy in Latin America: How neoliberal, how new? Development and Change 39 (5): 775-797.

Montambeault, Françoise and Camille Goirand. 2016. Between collective action and individual appropriation: The informal dimensions of participatory budgeting in Recife, Brazil. Politics \& Society, 44 (1): 143-171.

Moore, Kelly and Kyle Woolley. 2016. Direct Action. In Wiley Blackwell Encyclopedia of Sociology,ed.GeorgeRitzer, https://doi.org/10.1002/9781405165518.wbeosd067.pub2

Morrison, Carey-Ann, Lynda Johnston, and Robyn Longhurst. 2012. Critical geographies of love as spatial, relational and political. Progress in Human Geography 37 (4): 505-521.

Moser, Annalise. 2004. Happy heterogeneity? Feminism, development, and the grassroots Women's movement in Peru. Feminist Studies 30 (1): 211-237. 
Moyano, Maria Elena and Diana Miloslavich Túpac. 2000. The autobiography of María Elena Moyano: The life and death of a Peruvian activist. Gainesville: University Press of Florida.

Navarro, Marysa. 2001. The personal is political: Las Madres de Plaza de Mayo. In Power and popular protest: Latin American social movements, eds. Susan Eckstein and Manuel Garretón, 241-258. Berkeley: University of California Press.

Nepstad, Sharon Erickson. 2004. Persistent resistance: Commitment and community in the plowshares movement. Social Problems 51 (1): 43-60.

Nepstad, Sharon Erickson. 2007. Oppositional consciousness among the privileged: Remaking religion in the Central American solidarity movement. Critical Sociology 33 (4): 661-688.

Nepstad, Sharon Erickson, and Clifford Bob. 2006. When do leaders matter?: Hypotheses on leadership dynamics in social movements. Mobilization 11 (1): 1-22.

Neumann, Pamela. 2013. The gendered burden of development in Nicaragua. Gender and Society 27 (6): 799-820.

O’Reilly, Karen. 2012. Ethnographic returning, qualitative longitudinal research and the reflexive analysis of social practice. The Sociological Review 60: 518-536.

Olson, Mancur. 1965. The Logic of collective action: Public goods and the theory of groups. Cambridge: Harvard University Press.

Ortner, Sherry B. 1995. Resistance and the problem of ethnographic refusal. Comparative Studies in Society and History 37 (1): 173-193.

Oxhorn, Philip. 2011. Sustaining civil society: economic exchange, democracy, and the social construction of citizenship in Latin America. University Park: Pennsylvania State University Press.

Párraguez Sanchez, Leslie. 2012. La Reconstrucción de movimiento social en barrios críticos: El 
caso de la 'Coordinadora de Pobladores José María Caro' de Santiago de Chile. Revista Invi 27 (74): 217-246.

Penglase, Ben. 2009. States of insecurity: everyday emergencies, public secrets, and drug trafficker power in a Brazilian favela. PoLAR: Political and Legal Anthropology Review, 32 (1): 47-63.

Pérez, Leda M., and Pedro M. Llanos. 2015. ¿Al fondo del escalafón? Un estado de la cuestión sobre el trabajo doméstico remunerado en el Perú. Documento de Discusión (DD1501). Lima: Centro de Investigación de la Universidad del Pacífico.

Pérez, Leda M., and Pedro M. Llanos. 2017. Vulnerable women in a thriving country: An analysis of twenty-first-century domestic workers in Peru and recommendations for future research. Latin American Research Review 52 (4): 552-570.

Pérez, Marcos. 2018. Life histories and political commitment in a poor people's movement. Qualitative Sociology 41 (1): 89-109.

Perry, Keisha-Kahn. 2013. Black women against the land grab: The fight for racial justice in Brazil. University of Minnesota Press.

Pinsky, Dina. 2015. The sustained snapshot: Incidental ethnographic encounters in qualitative interview studies. Qualitative Research 15 (3): 281-295.

Polletta, Francesca. 2006. It was like a fever: Storytelling in protest and politics. The University of Chicago Press.

Puar, Jasbir K. 2009. Prognosis time: Towards a geopolitics of affect, debility and capacity. Women \& Performance: A Journal of Feminist Theory 19 (2): 161-172.

Quirós, Julieta. 2018. From exchange to inter-knowledge: Ethnography and the invisible facts of political work. Íconos 22 (60): 121-142. 
Ray, Raka, and Anna Korteweg. 1999. Women's movements in the third world:

Identity, mobilization, and autonomy. Annual Review of Sociology 25: 47-71.

Richards, Patricia. 2005. The politics of gender, human rights, and being indigenous in Chile. Gender \& Society 19 (2): 199-220.

Rousseau, Stephanie. 2006. Women's citizenship and neopopulism: Peru under the Fujimori Regime. Latin American Politics and Society. 48 (1): 117-141.

Rousseau, Stephanie. 2009. Women's citizenship in Peru: The paradoxes of neopopulism in Latin America. New York: Palgrave Macmillan.

Rubin, Jeffrey W. 1997. Ambiguity and contradiction in a radical popular movement. In Cultures of politics/politics of cultures. eds. Sonia E. Alvarez, Evelina Dagnino and Arturo Escobar, 141-164. Boulder: Westview Press.

Rubin, Jeffrey W., David Smilde and Benjamin Junge. 2014. Lived religion and lived citizenship in Latin America's zones of crisis: Introduction. Latin American Research Review 49: 726.

Smith, Christian. 1996. Disruptive Religion: The Force of Faith in Social Movement Activism. New York: Routledge Publishers.

Sternbach, Nancy Saporta, Marysa Navarro-Aranguren, Patricia Chuchryk, and Sonia E. Alvarez. 1992. Feminisms in Latin America: From Bogotá to San Bernardo. Signs 17 (2): 393-434.

Shepard, Benjamin. 2011. Play, creativity, and social movements: If I can't dance, it's not my revolution. New York: Routledge.

Singleton, Vicky and Steve Mee. 2017. Critical compassion: Affect, discretion and policy-care relations. The Sociological Review 65 (2): 130-149.

Silva, Eduardo. 2016. Indigenous people's movements, developments, and politics in Ecuador 
and Bolivia. In Handbook of social movements across Latin America, eds. Paul Almedia and Alan Cordero Ulate, 131-144. Dordrecht: Springer.

Thayer, Millie. 2010. Translations and refusals: Resignifying meanings as feminist political practice. Feminist Studies 36 (1): 200-230.

Thayer, Millie. 2017. The 'gray zone' between movements and markets: Brazilian feminists and the international aid chain. In Beyond Civil Society: Social Movements, Civic Participation and Democratic Contestation, eds. Sonia E. Alvarez, Gianpaolo Baiocchi, Agustín Lao Montes, Jeffrey Rubin and Millie Thayer, 141-155. Durham: Duke University Press.

Touraine, Alain. 1971. The post-industrial society; tomorrow's social history: Classes, conflicts and culture in the programmed society. New York: Random House.

White, David Gavin. 2009. Displacement, decentralization and reparation in postconflict Peru. Forced Migration Review 33: 44-46.

Whittier, Nancy. 1995. Feminist Generations: The Persistence of the Radical Feminist Movement. Philadelphia: Temple University Press.

Whittier, Nancy. 2009. The Politics of Child Sexual Abuse: Emotion, Social Movements, and the State. Oxford: Oxford University Press.

Yang, Goubin. 2000. The liminal effects of social movements: Red Guards and the transformation of identity. Sociological Forum 15 (2): 379-406.

Young, Michael P. 2007. Bearing witness against sin: The evangelical birth of the American social movement. Chicago: The University of Chicago Press. 
${ }^{1}$ Collective action projects in Peru have risen since the beginning of the century (Arce 2015; Carrión, Zárate, and Seligson 2012), particularly against extractive industries (Arce 2015; Bebbington et al. 2008; Bebbington 2012; Dietz 1998).

${ }^{2}$ Women were the most active participants in the campaign, for three major reasons: (1) they were more present in VES compared to the men, who were often working far away or had left their families altogether; (2) some women transferred skills in community kitchens and milk programs to become dirigentes; (3) women perceived the need to act in terms of the need to care for their children, not to help themselves. Gendered family life thus played a role in shaping their motivations to act.

${ }^{3}$ We have included each informant's place of origin, which we found to be related to their experiences with poverty and violence, but we did not find that place of origin shaped tensions or solidarities.

${ }^{4}$ In Peru, a census is taken on a single Sunday. All businesses, schools and other activities are shut down, and people are required to be in their homes. After a census worker has visited, a sticker is placed on the door, indicating the household has been counted. There are steep fines for absences. 